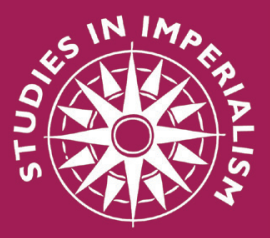

\title{
THE LANGUAGE OF EMPIRE
}

\section{Myths and Metaphors of Popular Imperialism, 1880-1918}

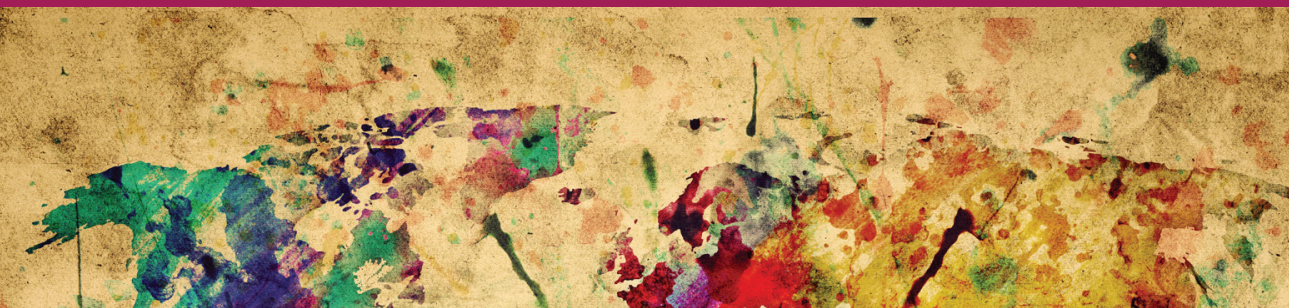




\section{- STUDIES IN-
IMPERIALISM}

General editor John M. MacKenzie

When the 'Studies in Imperialism' series was founded by Professor John M. MacKenzie more than thirty years ago, emphasis was laid upon the conviction that imperialism as a cultural phenomenon had as significant an effect on the dominant as on the subordinate societies'. With well over a hundred titles now published, this remains the prime concern of the series. Cross-disciplinary work has indeed appeared covering the full spectrum of cultural phenomena, as well as examining aspects of gender and sex, frontiers and law, science and the environment, language and literature, migration and patriotic societies, and much else. Moreover, the series has always wished to present comparative work on European and American imperialism, and particularly welcomes the submission of books in these areas. The fascination with imperialism, in all its aspects, shows no sign of abating, and this series will continue to lead the way in encouraging the widest possible range of studies in the field. Studies in Imperialism is fully organic in its development, always seeking to be at the cutting edge, responding to the latest interests of scholars and the needs of this ever-expanding area of scholarship. 


\section{\begin{tabular}{l} 
- STUDIES IN- \\
IMPERIALISM \\
\hline
\end{tabular}}

Propaganda and empire

The manipulation of British public opinion, 1880-1960 John M. MacKenzie

Imperialism and popular culture ed.

John M. MacKenzie

Ephemeral vistas

The Expositions Universelles, Great Exhibitions and World 's Fairs, 1851-1939 Paul Greenhalgh

'At duty's call'

A study in obsolete patriotism W. J. Reader

Images of the army

The military in British art, 1815-1914 J. W. M. Hichberger

The empire of nature

Hunting, conservation and British imperialism

John M. MacKenzie

'Benefits bestowed'?

Education and British imperialism ed. J. A. Mangan

Imperial medicine and indigenous societies

ed. David Arnold

Imperialism and juvenile literature

ed. Jeffrey Richards

Asia in Western fiction

ed. Robin W. Winks, James R. Rush

Making imperial mentalities

Socialisation and British imperialism ed. J. A. Mangan

Empire and sexuality

The British experience Ronald Hyam

Imperialism and the natural world

nameed. John M. MacKenzie

Emigrants and empire

British settlement in the dominions

between the wars ed. Stephen Constantine

Revolution and empire

English politics and the American colonies

in the seventeenth century Robert M. Bliss

Air power and colonial control

The Royal Air Force 1919-39 David E. Omissi

Acts of supremacy

The British Empire and the stage, 1790-1930

J. S. Bratton et al.

Policing the Empire

Government, authority and control, 1830-1940

ed. David Anderson, David Killingray

Policing and decolonisation

Nationalism, politics and the police, 1917-65

ed. David Anderson, David Killingray

The image of war

Popular imperialism and the military, 1850-1950

ed. John M. MacKenzie 


\section{The language of empire}

Myths and Metaphors of Popular

Imperialism, 1880-1918

Robert H. MacDonald

MANCHESTER

UNIVERSITY PRESS

Manchester 
Copyright ( Manchester University Press 1994

Published by MANCHESTER UNIVERSITY PRESS

ALTRINCHAM STREET, MANCHESTER, M1 7JA, UK

www.manchesteruniversitypress.co.uk

British Library cataloguing-in-publication data

A catalogue record for this book is available from the British Library

Library of Congress Cataloging-in-Publication Data

MacDonald, Robert H., 1934-

The language of empire : myths and metaphors of popular

imperialism, 1880-1918 / by Robert H. MacDonald,

p. cm. - (Studies in imperialism)

ISBN 0-7190-3749-2 (hard)

1. English literature - 19th century - History and criticism.

2. Imperialism - Great Britain - Public opinion - History - 19th century. 3.

Imperialism - Great Britain - Public opinion - History - 20th century. 4. English

literature -20 th century - History and criticism. 5. Popular literature - Great Britain -

History and criticism. 6. Imperialism in literature. 7. Myth in literature. 8. Metaphor.

I. Title. II. Series: Studies in imperialism (Manchester, England) PR468.I49M33 1994

$820.9^{\prime} 008$ - dc20 93-45568

ISBN 0719037492 hardback

The publisher has no responsibility for the persistence or accuracy of URLs for any external or third-party internet websites referred to in this book, and does not guarantee that any content on such websites is, or will remain, accurate or appropriate. 